The response to colour is without exception very good. This is to be expected, for the African's natural understanding of colour is obvious to any one who has seen with what care and taste he blends colours in his costume. The African, in fact, possesses every natural quality necessary to the artist and if he once discovers his true personality and gains independence of Western influence he will certainly succeed in producing work of a high order. The work exhibited shows that these five young men have taken their first step towards that end. (Communicated by DR. G. PFEFFER.)

\title{
Rhodes-Livingstone Institute of Central African Studies.
}

THE year I940 will mark not only the jubilee of the foundation of the two Rhodesias in I 890 by Cecil Rhodes, but also the centenary of the departure for Africa in 1840 of David Livingstone. It is proposed that this double anniversary should be commemorated in Northern Rhodesia by the establishment of a Rhodes-Livingstone Institute of Central African Studies which will serve as a combined memorial to these two famous men, in the fulfilment of whose ideals lies the best hope for the future of British Central Africa.

The Rhodes-Livingstone Institute is intended as a contribution to the scientific efforts now being made in various quarters to examine the effect upon native African society of the impact of European civilization, by the formation in Africa itself of a centre where the problem of establishing permanent and satisfactory relations between natives and non-natives-a problem of urgent importance where, as in Northern Rhodesia, mineral resources are being developed in the home of a primitive community-may form the subject of special study. The Institute will be situated at the town of Livingstone, the old capital of Northern Rhodesia, seven miles from the Victoria Falls of the River Zambezi, which forms the boundary between Northern and Southern Rhodesia, where the Government of Northern Rhodesia, generously helped by the Beit Railway Trust, the Council of the Royal Geographical Society, the Scottish National Memorial at Blantyre, and a number of individual benefactors, have already established a Museum which contains, in addition to objects of historical interest connected with David Livingstone, the nucleus of an important ethnological collection. This Museum is at present housed in what used to be the premises of the United Service Club, adjoining old Government House. It is proposed that these two buildings and the grounds in which they stand should be purchased and adapted to the purposes of the Institute at an estimated cost of $f_{1} 5,000$ and vested in the Trust which has been formed by recent legislation in Northern Rhodesia for its general and financial control.

As a preliminary to the foundation of the new Institute and the incorporation with it of the existing Museum, the Northern Rhodesian Government are appointing an expert in applied anthropology who will subsequently be provided with an assistant if funds are available. 
An influential group has made a public appeal for subscriptions in order that the scheme may be in full operation by 1940 and it is believed that some of our members will wish to be associated with the work. Cheques, which should be made payable to the Rhodes-Livingstone Trust, may be sent to any branch either of Barclays Bank, Ltd., or of Barclays Bank (Dominions, Colonial, and Overseas) or of the Standard Bank of South Africa, who have kindly agreed to receive them.

\section{Oxford University Summer School on Colonial Administration.}

THE success of the first Oxford University Summer School on Colonial Administration (under the Chairmanship of Professor R. Coupland and Miss Margery Perham) exceeded all expectations. It numbered I 70 members, housed at St. Hugh's College, and included administrative officers serving in nearly every British Colony or Protectorate. Africa, and in particular Nigeria, sent by far the largest contingents. The School, which lasted for a fortnight, was formally opened by the Rt. Hon. W. Ormsby Gore, Secretary of State for the Colonies, who emphasized the value of co-operation between those engaged in academic research and those doing the dayto-day work of administration. Lord Lugard gave the inaugural address, in the course of which he said that it would be impossible to overestimate the value of the study of native life. He spoke of premature detribalization as one of the most pressing problems, suggesting that the remedy might be found in making the village community an effective antidote to emigration.

The lecture courses were planned on broad, imaginative lines and covered a wide field. The first week was given up to large-scale surveys of international problems, political and economic (Sir Arthur Salter on world economic policies, Sir Alfred Zimmern on the international outlook, Professor Coupland on the humanitarian tradition, \&c.). Other lecturers gave historical and comparative accounts of the whole development of administrative machinery in countries with widely differing cultures (e.g. Sir Frederick Whyte on the Far East, Professor Laski on the Soviet experiment, Miss Headlam-Morley on the Totalitarian States, Professor Labouret, Professor A. Moeller and Professor de Wilde on the colonial policies of France, Belgium, and Holland respectively). Mr. John Maud discussed local government in England and Sir John Shuckburgh the organization of the British Colonial Office. These wider surveys led the way to more detailed discussions of special administrative problems in the Colonies during the second week. The School then listened to Lord Hailey describing the progress of the African Research Survey and sketching the comparative development of legal and judicial machinery in India and Africa. Sir Donald Cameron spoke on the policy of Indirect Rule, Miss Margery Perham on colonial administration in general, Dr. Lucy Mair on land tenure, Mr. C. F. Strickland on 